\title{
Formation of secondary organic aerosols from gas-phase emissions of heated cooking oils
}

\author{
Tengyu Liu ${ }^{1}$, Zijun Li ${ }^{2}$, ManNin Chan ${ }^{2,3}$, and Chak K. Chan ${ }^{1}$ \\ ${ }^{1}$ School of Energy and Environment, City University of Hong Kong, Hong Kong, China \\ ${ }^{2}$ Earth System Science Programme, The Chinese University of Hong Kong, Hong Kong, China \\ ${ }^{3}$ The Institute of Environment, Energy and Sustainability, The Chinese University of Hong Kong, Hong Kong, China \\ Correspondence to: Chak K. Chan (Chak.K.Chan@ cityu.edu.hk)
}

Received: 29 January 2017 - Discussion started: 31 January 2017

Revised: 25 April 2017 - Accepted: 15 May 2017 - Published: 20 June 2017

\begin{abstract}
Cooking emissions can potentially contribute to secondary organic aerosol (SOA) but remain poorly understood. In this study, formation of SOA from gas-phase emissions of five heated vegetable oils (i.e., corn, canola, sunflower, peanut and olive oils) was investigated in a potential aerosol mass (PAM) chamber. Experiments were conducted at $19-20^{\circ} \mathrm{C}$ and $65-70 \%$ relative humidity (RH). The characterization instruments included a scanning mobility particle sizer (SMPS) and a high-resolution time-offlight aerosol mass spectrometer (HR-TOF-AMS). The efficiency of SOA production, in ascending order, was peanut oil, olive oil, canola oil, corn oil and sunflower oil. The major SOA precursors from heated cooking oils were related to the content of monounsaturated fat and omega- 6 fatty acids in cooking oils. The average production rate of SOA, after aging at an $\mathrm{OH}$ exposure of $1.7 \times 10^{11}$ molecules $\mathrm{cm}^{-3} \mathrm{~s}$, was $1.35 \pm 0.30 \mu \mathrm{g} \mathrm{min}^{-1}, 3$ orders of magnitude lower compared with emission rates of fine particulate matter $\left(\mathrm{PM}_{2.5}\right)$ from heated cooking oils in previous studies. The mass spectra of cooking SOA highly resemble field-derived COA (cookingrelated organic aerosol) in ambient air, with $R^{2}$ ranging from 0.74 to 0.88 . The average carbon oxidation state $\left(\mathrm{OS}_{\mathrm{c}}\right)$ of SOA was -1.51 to -0.81 , falling in the range between ambient hydrocarbon-like organic aerosol (HOA) and semivolatile oxygenated organic aerosol (SV-OOA), indicating that SOA in these experiments was lightly oxidized.
\end{abstract}

\section{Introduction}

Organic aerosol (OA) is an important component of atmospheric particulate matter (PM), which influences air quality, climate and human health (Hallquist et al., 2009). A significant fraction of OA is secondary organic aerosol (SOA) (Zhang et al., 2007), formed via the oxidation of volatile organic compounds (VOCs) (Hallquist et al., 2009). However, chemical transport models generally underestimate SOA levels due to the unclear sources and formation processes of SOA (de Gouw et al., 2005; Heald et al., 2005; Johnson et al., 2006; Volkamer et al., 2006). Recently, primary semi-volatile and intermediate-volatility organic compounds (SVOCs and IVOCs) that can come from the evaporation of primary organic aerosol (POA) were found to form substantial SOA (Robinson et al., 2007; Donahue et al., 2009). Therefore, any source of POA may be associated with the production of SOA.

Cooking-related organic aerosol (COA), thought to be primary in origin, contributed $10-34.6 \%$ of the total OA in urban areas (Allan et al., 2010; Sun et al., 2011, 2012; Ge et al., 2012; Mohr et al., 2012; Crippa et al., 2013; Lee et al., 2015). Lee et al. (2015) found that COA even dominated the contribution to POA at roadside sites in the commercial and shopping area of Mongkok in Hong Kong. Cooking may be a large source of SOA in urban areas, yet the formation of SOA from cooking remains poorly understood. Kaltsonoudis et al. (2016) observed that the oxygen to carbon ratio $(\mathrm{O}: \mathrm{C})$ of OA from meat charbroiling increased from 0.09 to 0.30 after a few hours of chemical aging. The aged aerosol mass spectra have similarities with ambient COA factors in two 
major Greek cities. Hayes et al. (2015) modeled that cooking emissions contributed $19-35 \%$ of SOA mass in downtown Los Angeles during the California Research at the Nexus of Air Quality and Climate Change (CalNex) 2010 campaign. In their study, primary SVOCs and IVOCs from cooking emissions were modeled using the same parameters as those from vehicle exhaust, due to limited information about SOA formation from cooking (Hayes et al., 2015).

Heating cooking oils, a fundamental process of frying, was found to produce large amounts of fine particulate matter $\left(\mathrm{PM}_{2.5}\right)$ (Torkmahalleh et al., 2012; Gao et al., 2013) and VOCs (Katragadda et al., 2010; Klein et al., 2016a). The $\mathrm{PM}_{2.5}$ emission rate for peanut, canola, corn and olive oils heated at $197^{\circ} \mathrm{C}$ was shown to be as high as $54 \mathrm{mg} \mathrm{min}^{-1}$ (Torkmahalleh et al., 2012). Allan et al. (2010) postulated that cooking oils may contribute more to PM than the meat itself in urban areas of London and Manchester. Schauer et al. (2002) estimated that cooking seed oils might contribute a significant fraction of lighter $n$-alkanoic acids such as nonanoic acid in the atmosphere. The VOCs emitted from heated cooking oils were dominated by aldehydes (Klein et al., 2016a), which were suggested to be potential SOA precursors (Chacon-Madrid et al., 2010). Despite these previous efforts, there are still no available data regarding SOA formation from heated cooking oils.

The objective of this study is to characterize SOA formation from gas-phase emissions of heated cooking oils. The magnitude and composition of the SOA formed from gasphase emissions of heated cooking oils were evaluated and have been discussed for the first time in this paper.

\section{Materials and methods}

\subsection{PAM chamber}

SOA formation from gas-phase emissions of five different heated cooking oils was investigated in a potential aerosol mass (PAM) chamber, which has been described in detail elsewhere (Kang et al., 2007, 2011; Lambe et al., 2011a, 2015). Briefly, a PAM chamber is a continuous-flow stainless steel cylindrical reactor using high and controlled levels of oxidants to oxidize precursor gases to produce SOA. The volume is approximately $19 \mathrm{~L}$ (length $60 \mathrm{~cm}$, diameter $20 \mathrm{~cm}$ ). High $\mathrm{OH}$ exposures were produced through the photolysis of ozone irradiated by a UV lamp $(\lambda=254 \mathrm{~nm})$ in the presence of water vapor. Ozone was produced by an ozone generator (1000BT-12, ENALY, Japan) via irradiation of pure $\mathrm{O}_{2}$. The $\mathrm{OH}$ concentration was controlled by the flow rate of ozone in the PAM chamber, which was approximately $40 \mathrm{ppm}$ prior to dilution. The ozone concentration in the PAM reactor was adjusted to five different levels, ranging from 0.4 to $2.7 \mathrm{ppm}$. The total flow rate in the PAM chamber was set at $3 \mathrm{~L} \mathrm{~min}^{-1}$ by a mass flow controller, resulting in residence time of $380 \mathrm{~s}$. The corresponding upper limit of $\mathrm{OH}$ exposure at these op-

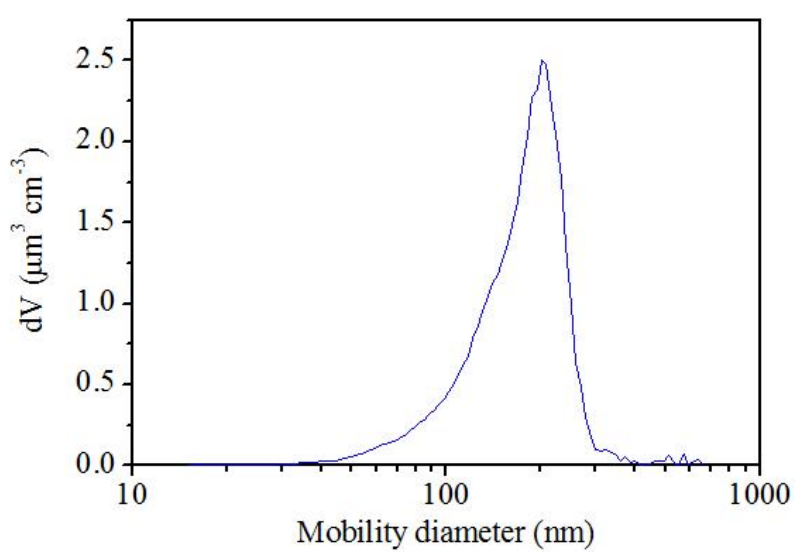

Figure 1. Size distribution of particle volume of SOA for sunflower oil at an $\mathrm{OH}$ exposure of $2.7 \times 10^{10}$ molecules $\mathrm{cm}^{-3} \mathrm{~s}$.

erating conditions was $1.7 \times 10^{11}$ molecules $\mathrm{cm}^{-3} \mathrm{~s}$, which is equivalent to 1.3 days of atmospheric oxidation, assuming an ambient $\mathrm{OH}$ concentration of $1.5 \times 10^{6}$ molecules $\mathrm{cm}^{-3}$ (Mao et al., 2009). The upper limit of $\mathrm{OH}$ exposure was determined by measuring the decay of $\mathrm{SO}_{2}$ (model T100, TAPI Inc, USA), following previous procedures (Kang et al., 2007; Lambe et al., 2011a). Peng et al. (2016) found that non-OH chemistry, especially reactions with $\mathrm{O}_{3}$, may play a role in the oxidation flow reactors for consumption of VOCs. According to Klein et al. (2016a), emissions of VOCs from heating cooking oils were dominated by saturated and unsaturated aldehydes. In this study, the ratio of $\mathrm{O}_{3}$ exposure to $\mathrm{OH}$ exposure ranged from $1.5 \times 10^{5}$ to $1.9 \times 10^{5}$, relatively lower than tropospheric values (Schmidt et al., 2014). At this $\mathrm{O}_{3 \exp } / \mathrm{OH}_{\text {exp }}$, ozonolysis of saturated and unsaturated aldehydes was negligible since the ratios of their ozonolysis rate constants to $\mathrm{OH}$ rate constants were in the range of $10^{-9}$ to $10^{-7}$. (Grosjean et al., 1993; Atkinson and Arey, 2003). Thus reactions of VOCs with $\mathrm{O}_{3}$ played a negligible role in this study. Before and after each experiment, the PAM reactor was cleaned by exposure to a high concentration of $\mathrm{OH}$ until the mass concentration of background particles was less than $5 \mu \mathrm{g} \mathrm{m}{ }^{-3}$.

The PAM chamber was designed with a large radius and a small surface-to-volume ratio to minimize wall effects. The transmission efficiency for particles at a mean mobility diameter $\left(D_{\mathrm{m}}\right)$ larger than $150 \mathrm{~nm}$ was greater than $80 \%$ (Lambe et al., 2011a). The wall loss of particles was considered to be small, as the particles larger than $150 \mathrm{~nm}$ accounted for greater than $70 \%$ of the aerosol mass (Fig. 1). Transmission efficiency of gases in the PAM chamber indicates that vapor wall losses in the PAM chamber are negligible (Lambe et al., 2011a). 


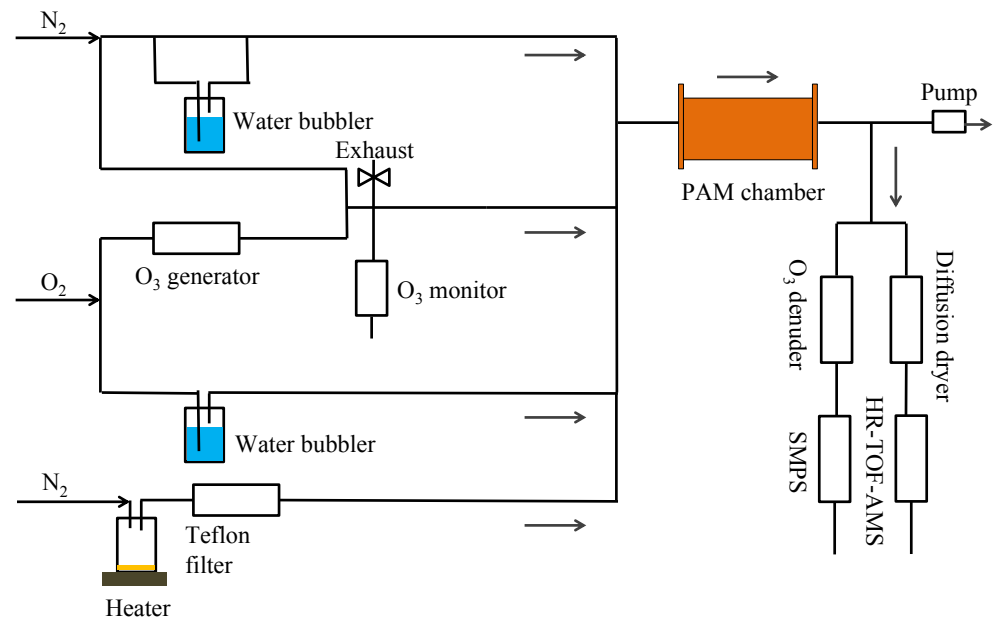

Figure 2. Schematic of the experimental setup.

\subsection{Experimental conditions}

A schematic of the experimental setup is shown in Fig. 2. The tested vegetable oils, purchased from a local supermarket, included canola (rapeseed), corn, sunflower, peanut and olive oils. For each experiment, $30 \mathrm{~mL}$ of vegetable oil was heated at approximately $220^{\circ} \mathrm{C}$ for $20 \mathrm{~min}$ in a $500 \mathrm{~mL}$ Pyrex bottle on an electric heating plate. Note that visible smoke was observed during heating of olive oil, possibly because the temperature was above the smoke point of olive oil. This high temperature may result in increased emissions of large aldehydes from olive oil, but may not significantly change the relative composition of emissions from other oils with higher smoke points (Klein et al., 2016a). Prior to introduction to the PAM chamber, particles from the heated oil emissions were removed using a Teflon filter. An unheated $2 \mathrm{~m}$ Teflon tube was used as the transfer line. The residence time in the transfer line was less than $2 \mathrm{~s}$, resulting in wall losses of VOCs less than $5 \%$ according to Liu et al. (2015). After $10 \mathrm{~min}$ of heating, the UV lamp was turned on and the emissions were exposed to high $\mathrm{OH}$ levels for approximately $1 \mathrm{~h}$. Once the UV lamp was turned off, the PAM reactor was flushed continuously using pure $\mathrm{N}_{2}$ and $\mathrm{O}_{2}$ until the aerosol mass was below $3 \mu \mathrm{g} \mathrm{m}^{-3}$. Then the experiment was repeated at another $\mathrm{OH}$ level. The $\mathrm{RH}$ and temperature of the PAM outflow were measured continuously (HMP 110, Vaisala Inc, Finland) and stabilized at $65-70 \%$ and $19-20^{\circ} \mathrm{C}$, respectively. The adjustment of RH was achieved by passing the pure $\mathrm{N}_{2}$ and $\mathrm{O}_{2}$ through water bubblers. Blank experiments were conducted in the absence of cooking oils under similar conditions to quantify the amount of aerosols formed from matrix gas when exposed to different $\mathrm{OH}$ levels.

POA emitted from heated cooking oils was also characterized in this study. For each test, $30 \mathrm{~mL}$ of vegetable oil was heated to $240^{\circ} \mathrm{C}$ for $2 \mathrm{~min}$ in a pan on an induction cooker. The emissions, after passing through a mixing cham- ber of $36 \mathrm{~L}$, were first diluted by a Dekati diluter (DI-1000, Dekati Ltd., Finland) by a factor of approximately 8 . Then $0.15 \mathrm{~L} \mathrm{~min}^{-1}$ of the total diluted flow was introduced to the PAM chamber, achieving a final dilution ratio of approximately 160 . No ozone was introduced to the PAM chamber during measurement, and the UV lamp was off. Temperature and $\mathrm{RH}$ were similar to those of the SOA formation experiments.

A scanning mobility particle sizer (SMPS, TSI Incorporated, USA, classifier model 3082, CPC model 3775) was used to measure particle number concentrations and size distributions. Particle size ranged from 15 to $661 \mathrm{~nm}$. An aerosol density of $1.4 \mathrm{~g} \mathrm{~cm}^{-3}$ was assumed to estimate the SOA mass from the particle volume concentration (Zhang et al., 2005). For the SOA formation experiments, the contribution from background organic aerosols was subtracted from the total organic aerosols. The maximum concentration of background organic aerosols was $8.4 \mu \mathrm{g} \mathrm{m}^{-3}$, almost negligible compared with the dozens to several hundreds of $\mu \mathrm{g} \mathrm{m}^{-3}$ of SOA formed in this study. The organic aerosol composition was characterized by a high-resolution timeof-flight aerosol mass spectrometer (HR-TOF-AMS, abbreviated as AMS hereafter, Aerodyne Research Incorporated, USA) (DeCarlo et al., 2006). A silica gel diffusion dryer was connected to the sampling line to remove water. The residence time in the dryer was approximately $8 \mathrm{~s}$, sufficient to reduce the RH to less than $30 \%$. The instrument was operated in the high-sensitivity $\mathrm{V}$ mode and high-resolution $\mathrm{W}$ mode alternating every $1 \mathrm{~min}$. The toolkit Squirrel $1.57 \mathrm{I}$ and Pika 1.16I were used to analyze the AMS data. The molar ratios of hydrogen to carbon $(\mathrm{H}: \mathrm{C})$ and oxygen to carbon $(\mathrm{O}: \mathrm{C})$ were determined with the improved-ambient method (Canagaratna et al., 2015). The ionization efficiency of AMS was calibrated using $300 \mathrm{~nm}$ ammonium nitrate particles. The particle-free matrix air, obtained by passing the air through a HEPA filter, was measured for at least $20 \mathrm{~min}$ 
before each experiment to determine the signals from major gases. The collection efficiency (CE) was corrected by comparing AMS mass concentrations to concurrent SMPS mass concentrations, following the methods of Gordon et al. (2014) and Liu et al. (2015). The value of CE varied from 0.38 to 0.78 in this study. Note that particles were not dried prior to SMPS measurements, which might lead to an overestimate of SOA mass due to the uptake of water by organics. Lambe et al. (2011b) investigated the cloud condensation nuclei activity of PAM-generated SOA and found that the hygroscopicity parameter $\kappa_{\text {org }}$ was linearly correlated with $\mathrm{O}: \mathrm{C}$ ratios. Based on their $\kappa_{\text {org }}-\mathrm{O}: \mathrm{C}$ relationship, we estimated an upper limit of $\kappa_{\text {org }}$ to be 0.089 in this study. The overestimate of SOA mass due to water uptake were thus determined to be less than $18 \%$ (Petters and Kreidenweis, 2007; Pajunoja et al., 2015).

\subsection{SOA production rate}

The SOA production rate (PR) was expressed as micrograms $(\mu \mathrm{g})$ of SOA produced per minute (min), calculated using the following equation, similar to calculation of emissions rates of primary particles from cooking (Klein et al., 2016a):

$\mathrm{PR}=[\mathrm{SOA}] \times \mathrm{DR} \times F$,

where [SOA] is the SOA concentration in $\mu \mathrm{g} \mathrm{m}^{-3}$, DR is the dilution ratio and $F$ is the flow rate in $\mathrm{m}^{3} \mathrm{~min}^{-1}$ of the carrier gas. All gas-phase emissions from heated cooking oils were assumed to be transported into the PAM chamber.

Emission rates are commonly used to normalize PM emissions from cooking activities (Torkmahalleh et al., 2012; Gao et al., 2013; Klein et al., 2016a, b). Here, the adoption of SOA $\mathrm{PR}$, similar to emission rates, facilitates the normalization of SOA production from cooking and direct comparison of the amount of primary emitted and secondary formed particles. Though SOA yields were not determined due to the lack of VOC concentrations, we believe that SOA PR is a useful metric for the estimation of SOA production from cooking and can be used for comparison among different studies. Note that PR is highly related to the experimental condition, especially $\mathrm{OH}$ exposure and temperature of the cooking oil.

\section{Results and discussion}

\subsection{SOA formation}

In Fig. 3, we plot the time series of RH, ozone and organic aerosol concentrations during the aging of gas-phase emissions from heated peanut oil. As described above, the ozone concentration prior to dilution was stable at approximately $40 \mathrm{ppm}$. The pulse of RH was caused by disconnection of the introduction line when changing the Teflon filter. During the initial $10 \mathrm{~min}$ of heating, the mass concentration of organics was close to the detection limit of the instrument, indicating

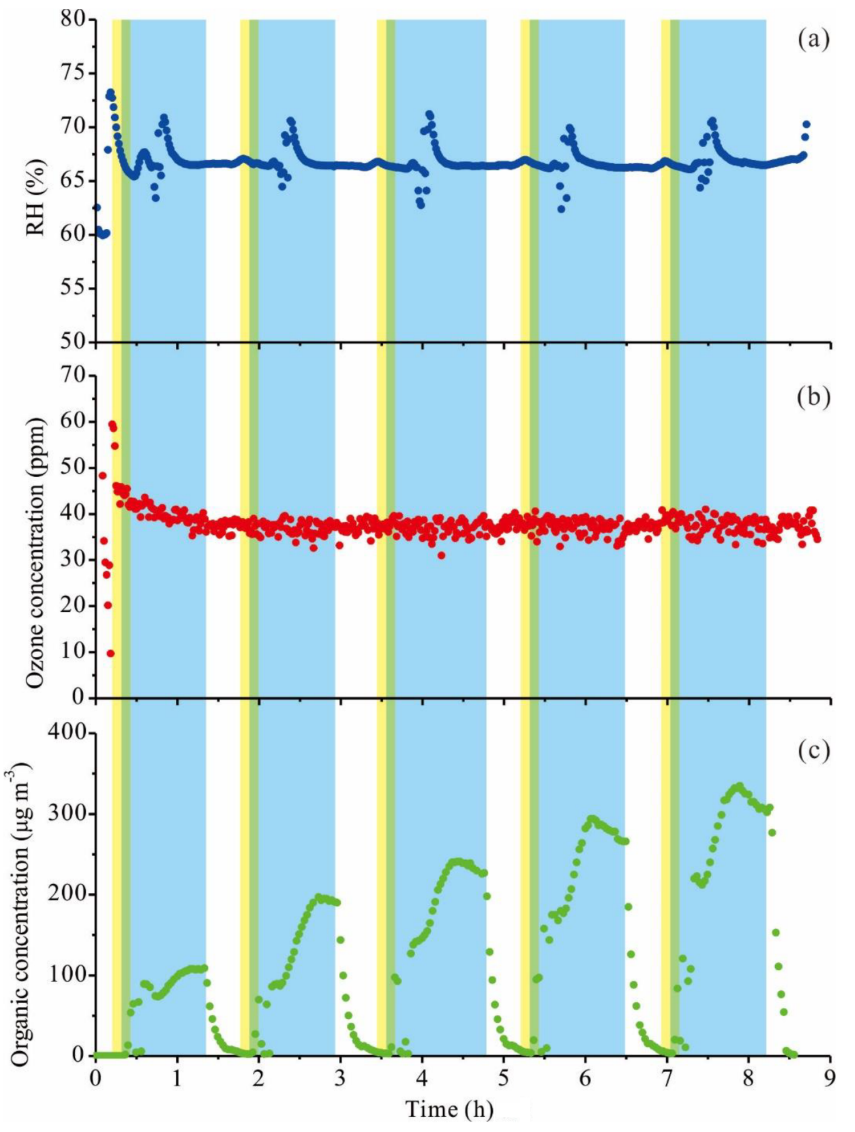

Figure 3. Time series of (a) relative humidity (RH), (b) ozone and (c) organic concentrations during the aging of gas-phase emissions from heated peanut oil. The yellow and light-blue regions represent the heating oil and $\mathrm{OH}$ exposure period, respectively. The green region is the overlap between heating oil and $\mathrm{OH}$ exposure period.

that POA emissions were thoroughly removed by the Teflon filter. During these periods of experiments where $\mathrm{OH}$ radicals were not present, we found that ozone chemistry had a negligible influence on SOA formation in this study. Immediately after oxidation was initiated by turning on the UV lamp, substantial SOA was formed, and its concentration stabilized after about $20 \mathrm{~min}$. The SOA concentration subsequently reported is the average for the steady period.

Figure 4 shows SOA concentration as a function of $\mathrm{OH}$ exposure and photochemical age in days during the aging of gas-phase emissions from different heated cooking oils. The $\mathrm{OH}$ exposure ranged from $2.7 \times 10^{10}$ to $1.7 \times$ $10^{11}$ molecules $\mathrm{cm}^{-3} \mathrm{~s}$, corresponding to $0.2-1.3$ days of photochemical age, assuming $24 \mathrm{~h}$ average ambient $\mathrm{OH}$ concentrations of $1.5 \times 10^{6}$ molecules $\mathrm{cm}^{-3}$ (Mao et al., 2009). For all experiments, the SOA concentration almost linearly increased from $41-107$ to $320-565 \mathrm{\mu g} \mathrm{m}^{-3}$ as $\mathrm{OH}$ exposure increased. This linear increase has also been observed from vehicle exhaust at a similar range of $\mathrm{OH}$ exposures (Tkacik et al., 2014). Typically, VOCs are oxidized through functional- 
Table 1. SOA production efficiency and type of fat content $(\%)^{\mathrm{a}}$ of different cooking oils.

\begin{tabular}{|c|c|c|c|c|c|c|}
\hline & \multirow[b]{2}{*}{$\left(\mu \mathrm{g}\right.$ molecules $\left.{ }^{-1} \mathrm{~s}^{-1}\right)$} & \multirow{2}{*}{$\begin{array}{l}\text { Saturated } \\
\qquad(\%)\end{array}$} & \multirow{2}{*}{$\begin{array}{r}\text { Monounsaturated } \\
\qquad(\%)\end{array}$} & \multicolumn{2}{|c|}{ Polyunsaturated } & \multirow{2}{*}{$\begin{array}{r}\text { Others } \\
(\%)\end{array}$} \\
\hline & & & & $\begin{array}{l}\text { Omega-6 } \\
(\%)\end{array}$ & Omega-3 & \\
\hline Sunflower & $3.82 \times 10^{-15}$ & 10 & 19 & 64 & 0 & 7 \\
\hline Corn & $3.31 \times 10^{-15}$ & 12 & 24 & 56 & 1 & 7 \\
\hline Canola & $2.68 \times 10^{-15}$ & 7 & 59 & 20 & 9 & 5 \\
\hline Olive & $2.55 \times 10^{-15}$ & 13 & 71 & 8 & 1 & 7 \\
\hline Peanut & $1.7 \times 10^{-15}$ & 16 & 44 & 31 & 0 & 9 \\
\hline
\end{tabular}

${ }^{a}$ The type of fat content of cooking oils was derived from skillsyouneed.com.

${ }^{\mathrm{b}}$ SOA production efficiency was presented as the slope of the fitted straight line to the SOA concentration vs. OH exposure.

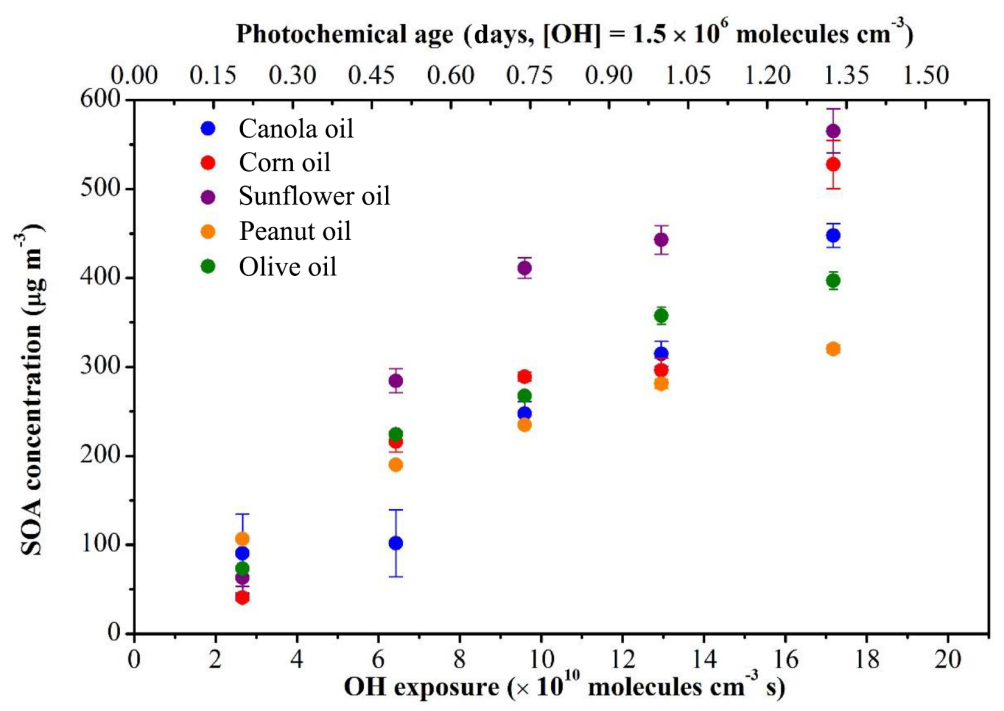

Figure 4. SOA concentration vs. $\mathrm{OH}$ exposure and photochemical age in days (at $[\mathrm{OH}]=1.5 \times 10^{6}$ molecules $\mathrm{cm}^{-3}$ ) during the aging of gas-phase emissions from different heated cooking oils. Error bars represent the standard deviation $(1 \sigma)$.

ization reactions to produce less volatile organics that readily condense to form SOA. Upon further oxidation, fragmentation reactions and cleavage of carbon bonds can occur and form more volatile products that reduce SOA levels (Kroll et al., 2009). In this study, functionalization reactions dominated SOA formation as reflected by the increase in SOA concentrations shown in Fig. 4.

The slope of the fitted straight line to the SOA data was calculated to estimate the efficiency of different cooking oils in producing SOA (Table 1). The efficiency of SOA production, in ascending order, was peanut oil, olive oil, canola oil, corn oil and sunflower oil. The slope of sunflower oil was $3.82 \times 10^{-15} \mu$ g molecules ${ }^{-1} \mathrm{~s}^{-1}$, more than 2 times that of peanut oil. The different slopes might be related to the emission rate and composition of VOCs from various cooking oils. Table 1 presents the type of fat content of the different cooking oils. It should be noted that the organic vapors studied here were not the specific fats present in the raw oils but the thermal breakdown products of fat lipids.
Unsaturated fat accounts for $75-88 \%$ of the total fat content. A multivariate linear regression was used to relate the SOA production efficiency to the fat content of cooking oils. The intercept was set to zero. The resulting equation was $Y=2.62 \times 10^{-17} X_{1}+4.71 \times 10^{-17} X_{2}$, where $Y$ is the SOA production efficiency $\left(\mu \mathrm{g}\right.$ molecules $\left.{ }^{-1} \mathrm{~s}^{-1}\right) ; X_{1}$ and $X_{2}$ represent the content of monounsaturated fat $(\%)$ and omega- 6 fatty acid $(\%)$ in cooking oil, respectively. The SOA production efficiency was strongly correlated $\left(R^{2}=0.97, p<0.05\right)$ with the content of monounsaturated fat and omega- 6 fatty acids. This indicated that the major SOA precursors from heated cooking oils were related to the content of monounsaturated fat and omega- 6 fatty acids in cooking oils. Moreover, omega-6 fatty acids dominated the contribution to SOA production. Omega- 6 fatty acids are a family of poly-unsaturated fatty acids that have in common a final carbon-carbon double bond in the $n-6$ position, counting from the methyl end (Simopoulos, 2002). The peroxyl radical reactions of omega6 fatty acids might emit long-chain aldehydes (Gardner, 
1989), which have been suggested as potential SOA precursors (Chacon-Madrid et al., 2010).

The average SOA PR from gas-phase emissions of the five cooking oils at an $\mathrm{OH}$ exposure of $1.7 \times 10^{11}$ molecules $\mathrm{cm}^{-3} \mathrm{~s}$ was calculated to be $1.35 \pm 0.30 \mu \mathrm{g} \mathrm{min}^{-1}$. Torkmahalleh et al. (2012) found that primary $\mathrm{PM}_{2.5}$ emission rates for peanut, canola, corn and olive oils heated at $197^{\circ} \mathrm{C}$ ranged from 3.7 to $54 \mathrm{mg} \mathrm{min}^{-1}$. $\mathrm{He}$ et al. (2004) reported a $\mathrm{PM}_{2.5}$ emission rate for frying in vegetable oils of $2.68 \pm 2.18 \mathrm{mg} \mathrm{min}^{-1}$. The SOA PR determined in this study was negligible compared with primary $\mathrm{PM}_{2.5}$ emission rates for heated cooking oils and frying in vegetable oils. However, our results may underestimate SOA production from cooking under real-world conditions. First, recent studies have demonstrated that the oxidation of IVOCs and SVOCs evaporated from POA could produce significant SOA (Donahue et al., 2006; Jimenez et al., 2009). In this study, POA from heated cooking oils was filtered. SVOCs and IVOCs might not evaporate from the filter given that they might be at saturation as the aerosol was cooled after the emissions. Second, emissions of SOA precursors will be enhanced when cooking food compared with heating cooking oils alone. For instance, long-chain aldehyde emissions from frying processes can be 10 times those of heated oil (Klein et al., 2016a). Large amounts of monoterpenes will be emitted when frying vegetables or cooking with herbs and spices (Klein et al., 2016a, b; Liu et al., 2017). These enhanced emitted precursors may significantly enhance SOA production. Finally, laboratory and tunnel studies indicate that SOA production from typical precursors and vehicle exhaust peaks at $\mathrm{OH}$ exposures higher than $5.0 \times 10^{11}$ molecules $\mathrm{cm}^{-3} \mathrm{~s}$ (Tkacik et al., 2014; Lambe et al., 2015). The relatively lower $\mathrm{OH}$ exposures in this study compared with typical conditions in the atmosphere may lead to the underestimation of cooking SOA.

\subsection{Mass spectra of POA and SOA}

Figure 5 shows high-resolution mass spectra of POA and SOA at an $\mathrm{OH}$ exposure of $2.7 \times 10^{10}$ molecules $\mathrm{cm}^{-3} \mathrm{~s}$ from heated canola oil. Other oils have similar mass spectra, as reflected in the good correlations shown in Table 2. The mass concentration of POA was approximately $35 \mu \mathrm{g} \mathrm{m}^{-3}$ for canola oil. The prominent peaks in POA from canola oil were $m / z 41$ and 55, followed by $m / z 29$ and 43. The $m / z$ 41, 43 and 55 were dominated by $\mathrm{C}_{3} \mathrm{H}_{5}^{+}, \mathrm{C}_{3} \mathrm{H}_{7}^{+}$and $\mathrm{C}_{4} \mathrm{H}_{7}^{+}$ion series, consistent with the previous observation by Allan et al. (2010). The $m / z 29$ was instead dominated by ion $\mathrm{CHO}^{+}$, which can be used as a tracer for organic compounds with alcohol and carbonyl functional groups, as a result of thermal decomposition of the oils (Lee et al., 2012). For the SOA mass spectra, the dominating peaks were $m / z 28$ and 29, followed by $\mathrm{m} / \mathrm{z} 43$ and 44 . The $\mathrm{m} / \mathrm{z} 28,29,43$ and 44 were dominated by $\mathrm{CO}^{+}, \mathrm{CHO}^{+}, \mathrm{C}_{2} \mathrm{H}_{3} \mathrm{O}^{+}$and $\mathrm{CO}_{2}^{+}$, respectively. For all cooking oils, the mass fractions of $\mathrm{m} / \mathrm{z} 28$ and 44 in

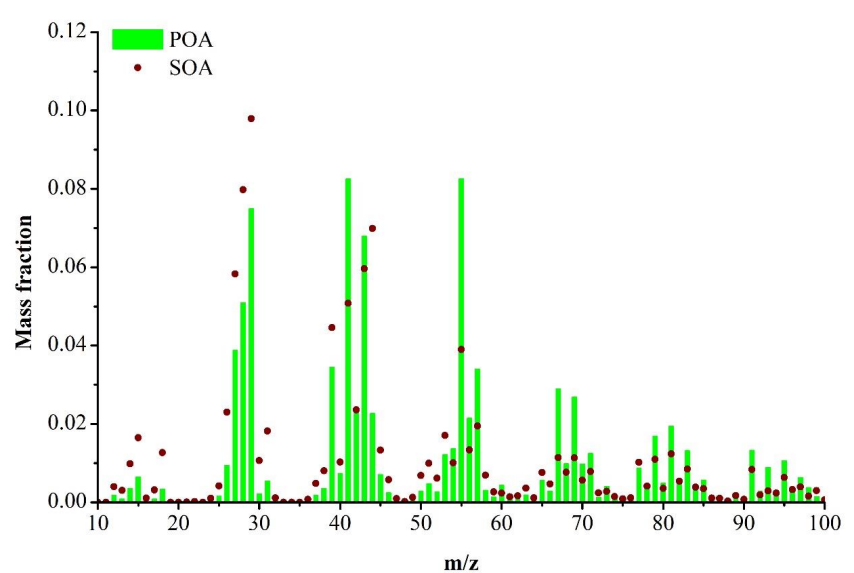

Figure 5. Mass spectra of POA and $\mathrm{SOA}$ at an $\mathrm{OH}$ exposure of $2.7 \times 10^{10}$ molecules $\mathrm{cm}^{-3} \mathrm{~s}$ from heated canola oil.

SOA were higher, while the mass fractions of $m / z 55$ and 57 in SOA were lower than those of the corresponding POA. The increase in mass fractions of the oxygen-containing ions in SOA mass spectra indicated the formation of oxidized organic aerosols.

The correlation coefficients $\left(R^{2}\right)$ between POA and SOA unit mass resolution (UMR) spectra of heated oil and COA resolved by positive matrix factorization (PMF) analysis (Lee et al., 2015) were calculated and summarized in Table 2 to evaluate their similarities. The POA mass spectra between different cooking oils exhibited strong correlations $\left(R^{2}>0.97\right)$ and agreed well with the ambient COA factor obtained at roadside sites in the commercial and shopping area of Mongkok in Hong Kong (Lee et al., 2015). The SOA mass spectra between different cooking oils displayed good correlations $\left(R^{2}>0.94\right)$, suggesting a high degree of similarity. The mass spectra of cooking SOA also greatly resemble POA and field-derived COA in ambient air, with $R^{2}$ ranging from 0.74 to 0.88 . Kaltsonoudis et al. (2016) also observed that the ambient COA factor in two major Greek cities in spring and summer strongly resembled the aged SOA from meat charbroiling in a smog chamber.

Fragments derived from the AMS data have been extensively used to explore the bulk compositions and properties of ambient organic aerosols (Zhang et al., 2005; Ng et al., 2010; Heald et al., 2010). Here, we use the approach of $\mathrm{Ng}$ et al. (2010) by plotting the fractions of the total organic signal at $m / z 43\left(f_{43}\right)$ vs. $m / z 44\left(f_{44}\right)$. The $m / z 43$ signal is abundant in $\mathrm{C}_{3} \mathrm{H}_{7}^{+}$and $\mathrm{C}_{2} \mathrm{H}_{3} \mathrm{O}^{+}$ions, indicating fresh, less oxidized organic aerosols. The $m / z 44$ signal, usually dominated by $\mathrm{CO}_{2}^{+}$and formed from the thermal decarboxylation of organic acids, is an indicator of highly oxygenated organic aerosols ( $\mathrm{Ng}$ et al., 2010).

In Fig. 6, we plot $f_{43}$ vs. $f_{44}$ of cooking SOA and SOA data from gasoline (Presto et al., 2014; Liu et al., 2015) and diesel (Presto et al., 2014) vehicle exhaust measured in a 
Table 2. Correlation coefficients $\left(R^{2}\right)$ between POA and SOA UMR mass spectra and ambient COA resolved by PMF.

\begin{tabular}{lccccccccccc}
\hline & CA P $^{\mathrm{a}}$ & CN P & SR P & PT P & OE P & CA S & CN S & SR S & PT S & OE S & COA $^{\mathrm{b}}$ \\
\hline CA P & 1.00 & 0.99 & 1.00 & 0.98 & 0.97 & 0.85 & 0.87 & 0.91 & 0.93 & 0.94 & 0.96 \\
CN P & 0.99 & 1.00 & 0.99 & 0.99 & 0.99 & 0.89 & 0.90 & 0.94 & 0.96 & 0.96 & 0.95 \\
SR P & 1.00 & 0.99 & 1.00 & 0.98 & 0.97 & 0.85 & 0.87 & 0.91 & 0.93 & 0.94 & 0.96 \\
PT P & 0.98 & 0.99 & 0.98 & 1.00 & 0.98 & 0.83 & 0.85 & 0.90 & 0.93 & 0.93 & 0.96 \\
OE P & 0.97 & 0.99 & 0.97 & 0.98 & 1.00 & 0.86 & 0.88 & 0.93 & 0.95 & 0.96 & 0.94 \\
CA S & 0.85 & 0.89 & 0.85 & 0.83 & 0.86 & 1.00 & 0.95 & 0.98 & 0.96 & 0.94 & 0.74 \\
CN S & 0.87 & 0.90 & 0.87 & 0.85 & 0.88 & 0.95 & 1.00 & 0.95 & 0.96 & 0.96 & 0.77 \\
SR S & 0.91 & 0.94 & 0.91 & 0.90 & 0.93 & 0.98 & 0.95 & 1.00 & 0.99 & 0.97 & 0.83 \\
PT S & 0.93 & 0.96 & 0.93 & 0.93 & 0.95 & 0.96 & 0.96 & 0.99 & 1.00 & 0.99 & 0.87 \\
OE S & 0.94 & 0.96 & 0.94 & 0.93 & 0.96 & 0.94 & 0.96 & 0.97 & 0.99 & 1.00 & 0.88 \\
\hline
\end{tabular}

${ }^{a} \mathrm{CA}, \mathrm{CN}, \mathrm{SR}, \mathrm{PT}$ and OE refer to canola, corn, sunflower, peanut and olive oil. P and S represent POA and SOA, respectively.

${ }^{\mathrm{b}}$ Lee et al. (2015).

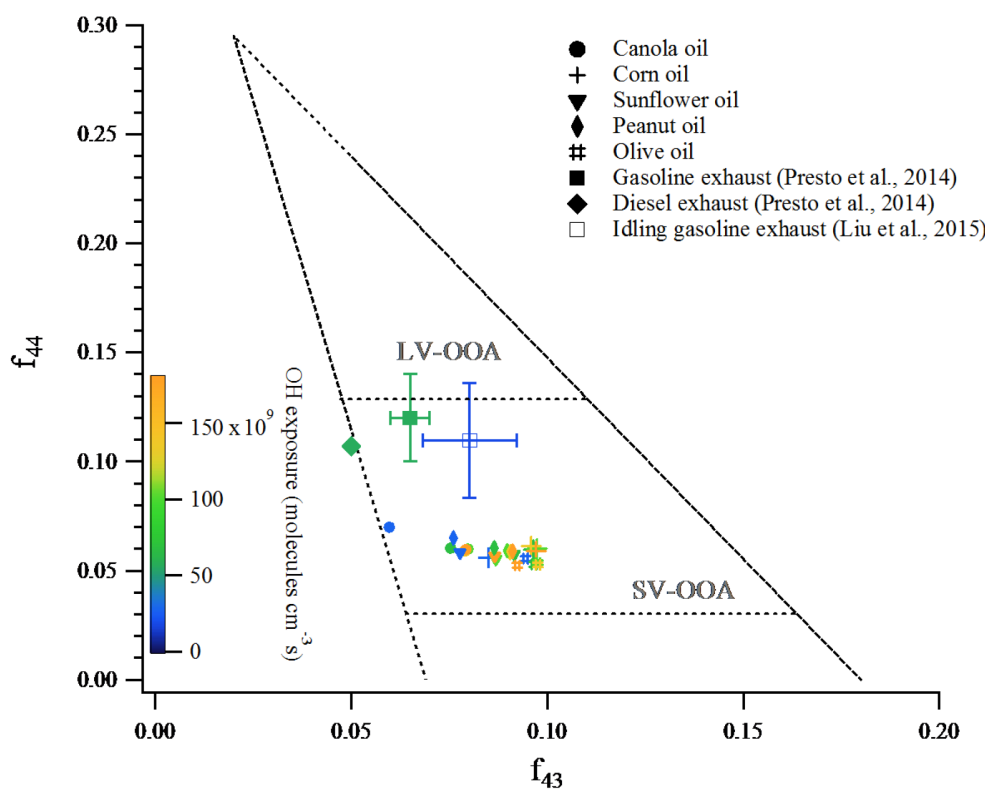

Figure 6. Fractions of total organic signal at $m / z 43\left(f_{43}\right)$ vs. $m / z\left(f_{44}\right)$ from SOA data in this work together with the triangle plot of Ng et al. (2010). SOA data from gasoline (Presto et al., 2014; Liu et al., 2015) and diesel (Presto et al., 2014) vehicle exhaust measured in smog chamber studies are shown. Data from this work and the literature are colored according to OH exposure. Ambient SV-OOA and LV-OOA regions are adapted from $\mathrm{Ng}$ et al. (2010).

smog chamber, together with the triangle defined by $\mathrm{Ng}$ et al. (2010) based on the analysis of ambient AMS data. The ambient low-volatility oxygenated OA (LV-OOA) and semivolatile OOA (SV-OOA) factors fall in the upper and lower regions of the triangle, respectively. $\mathrm{Ng}$ et al. (2010) proposed that aging would converge the $f_{43}$ and $f_{44}$ toward the triangle apex $\left(f_{43}=0.02, f_{44}=0.30\right)$. In this study, the $f_{43}$ and $f_{44}$ ranged from 0.06 to 0.10 and from 0.05 to 0.07 , respectively; they mainly lie in the lower portion of the SVOOA region. As shown in Fig. 6, SOA from gasoline and diesel vehicle exhaust at a similar range of $\mathrm{OH}$ exposures had $f_{44}$ values of $0.11-0.12$. Compared with vehicle exhaust, SOA formed from gas-phase emissions of heated cooking oils was less oxidized. The potential SOA precursors from heated cooking oils might be long-chain aldehydes, which are less volatile than SOA precursors such as aromatics and long-chain alkanes from vehicle exhaust. Generally, the presence of additional methylene and aldehyde reduce compound vapor pressure by factors of 3 and 22, respectively (Pankow and Asher, 2008). For example, the vapor pressure of $n$ tridecanal is approximately $14 \%$ of that of $n$-tridecane at $25^{\circ} \mathrm{C}$, as predicted by the group-contribution model (Pankow and Asher, 2008). A single polar moiety of first-generation products from long-chain aldehydes will have low enough volatility to condense, while more volatile aromatics and long-chain alkanes require more functionalization to form 

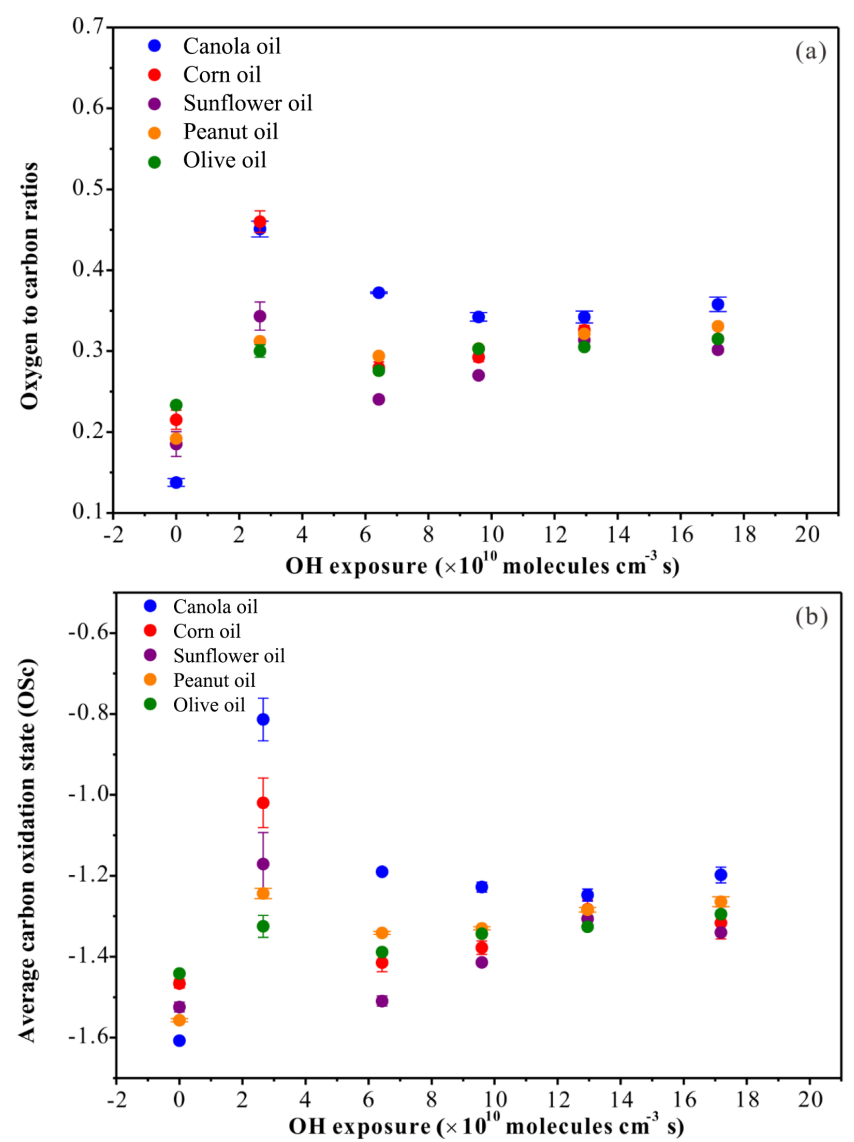

Figure 7. Evolution of (a) oxygen to carbon $(\mathrm{O}: \mathrm{C})$ molar ratios and (b) average carbon oxidation state $\left(\mathrm{OS}_{\mathrm{c}}\right)$ as a function of $\mathrm{OH}$ exposure during the aging of gas-phase emissions from different heated cooking oils, with error bars indicating standard error. Data at $[\mathrm{OH}]=0$ represent POA from cooking oils.

SOA (Donahue et al., 2012). Therefore, SOA formed from heated cooking oils was less oxidized. For each cooking oil, there was little change in $f_{44}$ and a slight increase in $f_{43}$ as $\mathrm{OH}$ exposure increased. The increased SOA mass may facilitate the partitioning of more volatile organics, leading to a slight increase in $f_{43}$ and little change in $f_{44}$. This is consistent with the observation of previous studies that the $f_{44}$ of SOA from aromatics and monoterpenes varied little and that $f_{43}$ increased slightly for SOA mass loadings higher than $100 \mu^{-3} \mathrm{~m}^{-3}$ (Ng et al., 2010; Kang et al., 2011).

\subsubsection{Chemical composition of SOA}

The $\mathrm{O}: \mathrm{C}$ ratio and the estimated average carbon oxidation state $\left(\mathrm{OS}_{\mathrm{c}}\right)\left(\mathrm{OS}_{\mathrm{c}} \approx 2 \times \mathrm{O}: \mathrm{C}-\mathrm{H}: \mathrm{C}\right)$ (Kroll et al., 2011) can be used to evaluate the degree of oxidation of organic aerosols. Figure 7 shows the evolution of $\mathrm{O}: \mathrm{C}$ ratios and $\mathrm{OS}_{\mathrm{c}}$ of SOA from heated cooking oils as a $\mathrm{O}: \mathrm{C}$ ratios and $\mathrm{OS}_{\mathrm{c}}$ of SOA from heated cooking oils as a function of $\mathrm{OH}$ exposure, together with the POA data. The $\mathrm{O}: \mathrm{C}$ ratios and
$\mathrm{OS}_{\mathrm{c}}$ of POA were in the range of 0.14 to 0.23 and -1.61 to -1.44 , respectively, comparable to those of POA from meat charbroiling (Kaltsonoudis et al., 2016). As shown in Fig. 7, for each cooking oil, the $\mathrm{O}: \mathrm{C}$ and $\mathrm{OS}_{\mathrm{c}}$ of SOA displayed similar trends, initially decreasing rapidly and then increasing slowly or leveling off (for canola oil only). In this study, the increased SOA mass loadings led to the rapid decrease in the oxidation degree when the $\mathrm{OH}$ exposure increased from $2.7 \times 10^{10}$ to $6.4 \times 10^{10}$ molecules $\mathrm{cm}^{-3} \mathrm{~s}$. As $\mathrm{OH}$ exposure and the resulting $\mathrm{OA}$ mass loadings further increase, even less oxidized and more volatile organics partition into the particle phase and thus decrease the oxidation degree (Donahue et al., 2006). The difference in O:C for different cooking oils at the same $\mathrm{OH}$ exposure may be attributed to the differences in gas-phase SOA precursors. In general, the $\mathrm{O}: \mathrm{C}$ ratios of SOA formed from gas-phase emissions of heated cooking oils ranged from 0.24 to 0.46 at $\mathrm{OH}$ exposures of $2.7 \times 10^{10}-1.7 \times 10^{11}$ molecules $\mathrm{cm}^{-3} \mathrm{~s}$. The $\mathrm{OS}_{\mathrm{c}}$ of cooking SOA was -1.51 to -0.81 , falling in the range between ambient hydrocarbon-like organic aerosol $\left(\mathrm{HOA}, \mathrm{OS}_{\mathrm{c}}=-1.69\right)$ and SV-OOA $\left(\mathrm{OS}_{\mathrm{c}}=-0.57\right)$ corrected by the improved-ambient method (Canagaratna et al., 2015). As suggested by Canagaratna et al. (2015), the $\mathrm{OS}_{\mathrm{c}}$ is more robust than the $f_{43} / f_{44}$ relationship for evaluating the oxidation degree of organic aerosols, as the former has been estimated based on the full spectra.

In Fig. 8 we plot the $\mathrm{H}: \mathrm{C}$ and $\mathrm{O}: \mathrm{C}$ molar ratios of POA and SOA from heated cooking oils on a Van Krevelen diagram. The cooking data fell along a line with a slope of approximately 0 , suggesting the chemistry of SOA formation in this study was alcohol/peroxide formation (Heald et al., 2010; Ng et al., 2011). This slope is different from ambient OA data of -0.8 determined by the improved-ambient method (Heald et al., 2010). It is also different from vehicle exhaust data, with slopes ranging from -0.59 to -0.36 (Presto et al., 2014; Liu et al., 2015).

\section{Conclusions}

Formation of SOA from gas-phase emissions of heated cooking oils was investigated in a PAM chamber at $\mathrm{OH}$ exposures of $2.7 \times 10^{10}$ to $1.7 \times 10^{11}$ molecules $\mathrm{cm}^{-3} \mathrm{~s}$. The $\mathrm{OS}_{\mathrm{c}}$ and $f_{43}-f_{44}$ relationship indicated that the SOA formed was lightly oxidized. The mass spectra of SOA highly resembled POA from heated cooking oils and COA factors in ambient air. The major SOA precursors from heated cooking oils were related to the content of monounsaturated fat and omega- 6 fatty acids in cooking oils. Considering that animal fats such as pork and chicken fat are also abundant in monounsaturated fat and omega- 6 fatty acids, gas-phase emissions from cooking animal fat might also produce SOA. It is important to note that the reported SOA data only related to gas-phase emissions from heated cooking oils. The large amounts of POA emitted from cooking oils may also form SOA after photo- 


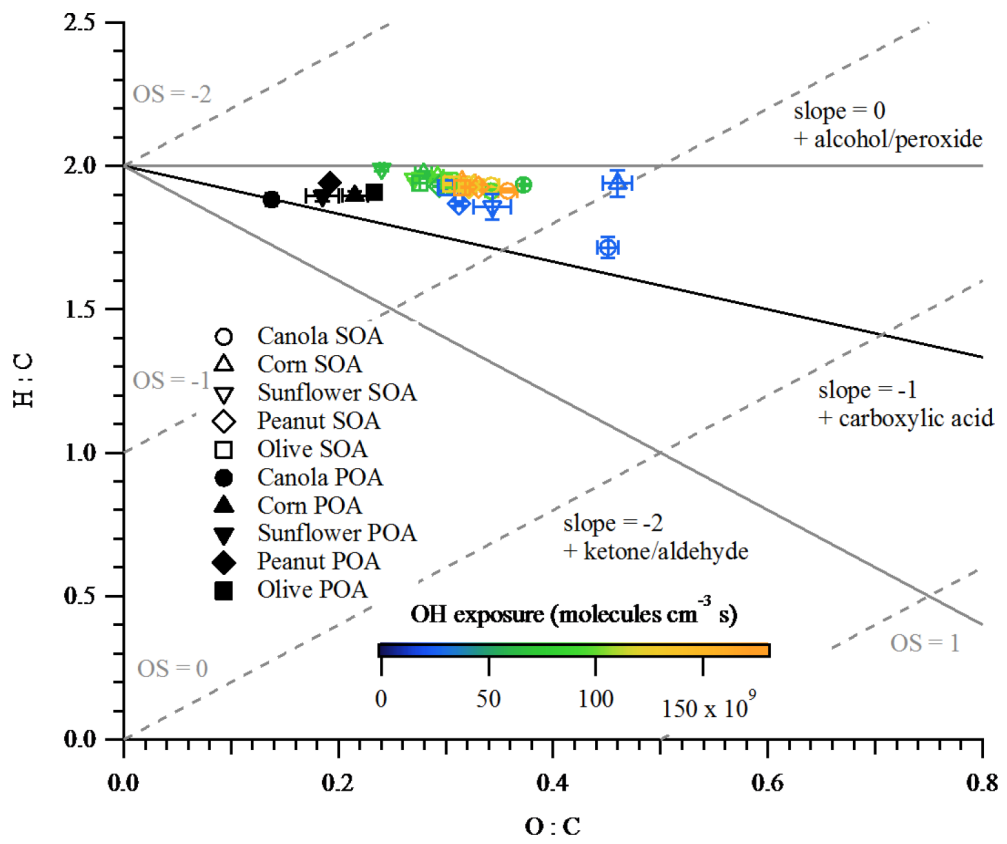

Figure 8. Van Krevelen diagram of POA and SOA from different heated cooking oils. Error bars represent the standard deviations (1 $\sigma$ ). SOA data are colored by $\mathrm{OH}$ exposure. Average carbon oxidation states from Kroll et al. (2011) and functionalization slopes from Heald et al. (2010) are shown for reference.

chemical aging. More work is needed to investigate SOA formation from emissions of cooking oils and food. In addition, gas-phase SOA precursors were not characterized and therefore provided limited information on SOA yields from cooking; we recommend that future work validate our results and perform similar experiments, with gas-phase SOA precursors characterized.

Data availability. The data used in this publication are available to the community and can be accessed by request to the corresponding author.

Competing interests. The authors declare that they have no conflict of interest.

Acknowledgements. The work described in this paper was partially sponsored by Project No. 41675117, supported by the National Natural Science Foundation of China, and was partially supported by the Shenzhen Research Institute, City University of Hong Kong. Zijun Li and ManNin Chan are supported by a Direct Grant for Research (4053159), The Chinese University of Hong Kong. Chak K. Chan would like to thank the Hong Kong University of Science and Technology for the use of the AMS.

Edited by: Jason Surratt

Reviewed by: two anonymous referees

\section{References}

Allan, J. D., Williams, P. I., Morgan, W. T., Martin, C. L., Flynn, M. J., Lee, J., Nemitz, E., Phillips, G. J., Gallagher, M. W., and Coe, H.: Contributions from transport, solid fuel burning and cooking to primary organic aerosols in two UK cities, Atmos. Chem. Phys., 10, 647-668, https://doi.org/10.5194/acp-10-6472010, 2010.

Atkinson, R. and Arey, J.: Atmospheric Degradation of Volatile Organic Compounds, Chem. Rev., 103, 4605-4638, https://doi.org/10.1021/cr0206420, 2003.

Canagaratna, M. R., Jimenez, J. L., Kroll, J. H., Chen, Q., Kessler, S. H., Massoli, P., Hildebrandt Ruiz, L., Fortner, E., Williams, L. R., Wilson, K. R., Surratt, J. D., Donahue, N. M., Jayne, J. T., and Worsnop, D. R.: Elemental ratio measurements of organic compounds using aerosol mass spectrometry: characterization, improved calibration, and implications, Atmos. Chem. Phys., 15, 253-272, https://doi.org/10.5194/acp-15-253-2015, 2015.

Chacon-Madrid, H. J., Presto, A. A., and Donahue, N. M.: Functionalization vs. fragmentation: n-aldehyde oxidation mechanisms and secondary organic aerosol formation, Phys. Chem. Chem. Phys., 12, 13975-13982, https://doi.org/10.1039/C0CP00200C, 2010.

Crippa, M., DeCarlo, P. F., Slowik, J. G., Mohr, C., Heringa, M. F., Chirico, R., Poulain, L., Freutel, F., Sciare, J., Cozic, J., Di Marco, C. F., Elsasser, M., Nicolas, J. B., Marchand, N., Abidi, E., Wiedensohler, A., Drewnick, F., Schneider, J., Borrmann, S., Nemitz, E., Zimmermann, R., Jaffrezo, J.-L., Prévôt, A. S. H., and Baltensperger, U.: Wintertime aerosol chemical composition and source apportionment of the organic fraction in the metropolitan area of Paris, Atmos. Chem. Phys., 13, 961981, https://doi.org/10.5194/acp-13-961-2013, 2013. 
DeCarlo, P. F., Kimmel, J. R., Trimborn, A., Northway, M. J., Jayne, J. T., Aiken, A. C., Gonin, M., Fuhrer, K., Horvath, T., Docherty, K. S., Worsnop, D. R., and Jimenez, J. L.: Field-Deployable, High-Resolution, Time-ofFlight Aerosol Mass Spectrometer, Anal. Chem., 78, 8281-8289, https://doi.org/10.1021/ac061249n, 2006.

de Gouw, J. A., Middlebrook, A. M., Warneke, C., Goldan, P. D., Kuster, W. C., Roberts, J. M., Fehsenfeld, F. C., Worsnop, D. R., Canagaratna, M. R., Pszenny, A. A. P., Keene, W. C., Marchewka, M., Bertman, S. B., and Bates, T. S.: Budget of organic carbon in a polluted atmosphere: Results from the New England Air Quality Study in 2002, J. Geophys. Res., 110, D16305, https://doi.org/10.1029/2004JD005623, 2005.

Donahue, N. M., Robinson, A. L., Stanier, C. O., and Pandis, S. N.: Coupled Partitioning, Dilution, and Chemical Aging of Semivolatile Organics, Environ. Sci. Technol., 40, 2635-2643, https://doi.org/10.1021/es052297c, 2006.

Donahue, N. M., Robinson, A. L., and Pandis, S. N.: Atmospheric organic particulate matter: From smoke to secondary organic aerosol, Atmos. Environ., 43, 94-106, https://doi.org/10.1016/j.atmosenv.2008.09.055, 2009.

Donahue, N. M., Kroll, J. H., Pandis, S. N., and Robinson, A. L.: A two-dimensional volatility basis set - Part 2: Diagnostics of organic-aerosol evolution, Atmos. Chem. Phys., 12, 615-634, https://doi.org/10.5194/acp-12-615-2012, 2012.

Gao, J., Cao, C. S., Wang, L., Song, T. H., Zhou, X., Yang, J., and Zhang, X.: Determination of Size-Dependent Source Emission Rate of Cooking-Generated Aerosol Particles at the Oil-Heating Stage in an Experimental Kitchen, Aerosol Air Qual. Res., 13, 488-496, https://doi.org/10.4209/aaqr.2012.09.0238, 2013.

Gardner, H. W.: Oxygen radical chemistry of polyunsaturated fatty acids, Free Radical Bio. Med., 7, 65-86, https://doi.org/10.1016/0891-5849(89)90102-0, 1989.

Ge, X., Setyan, A., Sun, Y., and Zhang, Q.: Primary and secondary organic aerosols in Fresno, California during wintertime: Results from high resolution aerosol mass spectrometry, J. Geophys. Res., 117, D19301, https://doi.org/10.1029/2012JD018026, 2012.

Gordon, T. D., Presto, A. A., May, A. A., Nguyen, N. T., Lipsky, E. M., Donahue, N. M., Gutierrez, A., Zhang, M., Maddox, C., Rieger, P., Chattopadhyay, S., Maldonado, H., Maricq, M. M., and Robinson, A. L.: Secondary organic aerosol formation exceeds primary particulate matter emissions for lightduty gasoline vehicles, Atmos. Chem. Phys., 14, 4661-4678, https://doi.org/10.5194/acp-14-4661-2014, 2014.

Grosjean, D., Grosjean, E., and Williams, E. L.: Rate constants for the gas-phase reactions of ozone with unsaturated alcohols, esters, and carbonyls, Int. J. Chem. Kinet., 25, 783-794, https://doi.org/10.1002/kin.550250909, 1993.

Hallquist, M., Wenger, J. C., Baltensperger, U., Rudich, Y., Simpson, D., Claeys, M., Dommen, J., Donahue, N. M., George, C., Goldstein, A. H., Hamilton, J. F., Herrmann, H., Hoffmann, T., Iinuma, Y., Jang, M., Jenkin, M. E., Jimenez, J. L., Kiendler-Scharr, A., Maenhaut, W., McFiggans, G., Mentel, Th. F., Monod, A., Prévôt, A. S. H., Seinfeld, J. H., Surratt, J. D., Szmigielski, R., and Wildt, J.: The formation, properties and impact of secondary organic aerosol: current and emerging issues, Atmos. Chem. Phys., 9, 5155-5236, https://doi.org/10.5194/acp9-5155-2009, 2009.
Hayes, P. L., Carlton, A. G., Baker, K. R., Ahmadov, R., Washenfelder, R. A., Alvarez, S., Rappenglück, B., Gilman, J. B., Kuster, W. C., de Gouw, J. A., Zotter, P., Prévôt, A. S. H., Szidat, S., Kleindienst, T. E., Offenberg, J. H., Ma, P. K., and Jimenez, J. L.: Modeling the formation and aging of secondary organic aerosols in Los Angeles during CalNex 2010, Atmos. Chem. Phys., 15, 5773-5801, https://doi.org/10.5194/acp-15-5773-2015, 2015.

He, C., Morawska, L., Hitchins, J., and Gilbert, D.: Contribution from indoor sources to particle number and mass concentrations in residential houses, Atmos. Environ., 38, 3405-3415, https://doi.org/10.1016/j.atmosenv.2004.03.027, 2004.

Heald, C. L., Jacob, D. J., Park, R. J., Russell, L. M., Huebert, B. J., Seinfeld, J. H., Liao, H., and Weber, R. J.: A large organic aerosol source in the free troposphere missing from current models, Geophys. Res. Lett., 32, L18809, https://doi.org/10.1029/2005GL023831, 2005.

Heald, C. L., Kroll, J. H., Jimenez, J. L., Docherty, K. S., DeCarlo, P. F., Aiken, A. C., Chen, Q., Martin, S. T., Farmer, D. K., and Artaxo, P.: A simplified description of the evolution of organic aerosol composition in the atmosphere, Geophys. Res. Lett., 37, L08803, https://doi.org/10.1029/2010gl042737, 2010.

Jimenez, J. L., Canagaratna, M. R., Donahue, N. M., Prevot, A. S. H., Zhang, Q., Kroll, J. H., DeCarlo, P. F., Allan, J. D., Coe, H., Ng, N. L., Aiken, A. C., Docherty, K. S., Ulbrich, I. M., Grieshop, A. P., Robinson, A. L., Duplissy, J., Smith, J. D., Wilson, K. R., Lanz, V. A., Hueglin, C., Sun, Y. L., Tian, J., Laaksonen, A., Raatikainen, T., Rautiainen, J., Vaattovaara, P., Ehn, M., Kulmala, M., Tomlinson, J. M., Collins, D. R., Cubison, M. J. E., Dunlea, J., Huffman, J. A., Onasch, T. B., Alfarra, M. R., Williams, P. I., Bower, K., Kondo, Y., Schneider, J., Drewnick, F., Borrmann, S., Weimer, S., Demerjian, K., Salcedo, D., Cottrell, L., Griffin, R., Takami, A., Miyoshi, T., Hatakeyama, S., Shimono, A., Sun, J. Y., Zhang, Y. M., Dzepina, K., Kimmel, J. R., Sueper, D., Jayne, J. T., Herndon, S. C., Trimborn, A. M., Williams, L. R., Wood, E. C., Middlebrook, A. M., Kolb, C. E., Baltensperger, U., and Worsnop, D. R.: Evolution of Organic Aerosols in the Atmosphere, Science, 326, 1525-1529, https://doi.org/10.1126/science.1180353, 2009.

Johnson, D., Utembe, S. R., Jenkin, M. E., Derwent, R. G., Hayman, G. D., Alfarra, M. R., Coe, H., and McFiggans, G.: Simulating regional scale secondary organic aerosol formation during the TORCH 2003 campaign in the southern UK, Atmos. Chem. Phys., 6, 403-418, https://doi.org/10.5194/acp-6403-2006, 2006.

Kaltsonoudis, C., Kostenidou, E., Louvaris, E., Psichoudaki, M., Tsiligiannis, E., Florou, K., Liangou, A., and Pandis, S. N.: Characterization of fresh and aged organic aerosol emissions from meat charbroiling, Atmos. Chem. Phys. Discuss., https://doi.org/10.5194/acp-2016-979, in review, 2016.

Kang, E., Root, M. J., Toohey, D. W., and Brune, W. H.: Introducing the concept of Potential Aerosol Mass (PAM), Atmos. Chem. Phys., 7, 5727-5744, https://doi.org/10.5194/acp-7-5727-2007, 2007.

Kang, E., Toohey, D. W., and Brune, W. H.: Dependence of SOA oxidation on organic aerosol mass concentration and $\mathrm{OH}$ exposure: experimental PAM chamber studies, Atmos. Chem. Phys., 11, 1837-1852, https://doi.org/10.5194/acp-11-1837-2011, 2011.

Katragadda, H. R., Fullana, A., Sidhu, S., and CarbonellBarrachina, Á. A.: Emissions of volatile aldehydes 
from heated cooking oils, Food Chem., 120, 59-65, https://doi.org/10.1016/j.foodchem.2009.09.070, 2010.

Klein, F., Platt, S. M., Farren, N. J., Detournay, A., Bruns, E. A., Bozzetti, C., Daellenbach, K. R., Kilic, D., Kumar, N. K., Pieber, S. M., Slowik, J. G., Temime-Roussel, B., Marchand, N., Hamilton, J. F., Baltensperger, U., Prévôt, A. S. H., and El Haddad, I.: Characterization of Gas-Phase Organics Using Proton Transfer Reaction Time-of-Flight Mass Spectrometry: Cooking Emissions, Environ. Sci. Technol., 50, 1243-1250, https://doi.org/10.1021/acs.est.5b04618, 2016a.

Klein, F., Farren, N. J., Bozzetti, C., Daellenbach, K. R., Kilic, D., Kumar, N. K., Pieber, S. M., Slowik, J. G., Tuthill, R. N., Hamilton, J. F., Baltensperger, U., Prévôt, A. S. H., and El Haddad, I.: Indoor terpene emissions from cooking with herbs and pepper and their secondary organic aerosol production potential, Scientific Reports, 6, 36623, https://doi.org/10.1038/srep36623, 2016b.

Kroll, J. H., Smith, J. D., Che, D. L., Kessler, S. H., Worsnop, D. R., and Wilson, K. R.: Measurement of fragmentation and functionalization pathways in the heterogeneous oxidation of oxidized organic aerosol, Phys. Chem. Chem. Phys., 11, 8005-8014, https://doi.org/10.1039/B905289E, 2009.

Kroll, J. H., Donahue, N. M., Jimenez, J. L., Kessler, S. H., Canagaratna, M. R., Wilson, K. R., Altieri, K. E., Mazzoleni, L. R., Wozniak, A. S., Bluhm, H., Mysak, E. R., Smith, J. D., Kolb, C. E., and Worsnop, D. R.: Carbon oxidation state as a metric for describing the chemistry of atmospheric organic aerosol, Nature Chemistry, 3, 133-139, 2011.

Lambe, A. T., Ahern, A. T., Williams, L. R., Slowik, J. G., Wong, J. P. S., Abbatt, J. P. D., Brune, W. H., Ng, N. L., Wright, J. P., Croasdale, D. R., Worsnop, D. R., Davidovits, P., and Onasch, T. B.: Characterization of aerosol photooxidation flow reactors: heterogeneous oxidation, secondary organic aerosol formation and cloud condensation nuclei activity measurements, Atmos. Meas. Tech., 4, 445-461, https://doi.org/10.5194/amt-4445-2011, 2011a.

Lambe, A. T., Onasch, T. B., Massoli, P., Croasdale, D. R., Wright, J. P., Ahern, A. T., Williams, L. R., Worsnop, D. R., Brune, W. H., and Davidovits, P.: Laboratory studies of the chemical composition and cloud condensation nuclei (CCN) activity of secondary organic aerosol (SOA) and oxidized primary organic aerosol (OPOA), Atmos. Chem. Phys., 11, 8913-8928, https://doi.org/10.5194/acp-11-8913-2011, 2011b.

Lambe, A. T., Chhabra, P. S., Onasch, T. B., Brune, W. H., Hunter, J. F., Kroll, J. H., Cummings, M. J., Brogan, J. F., Parmar, Y., Worsnop, D. R., Kolb, C. E., and Davidovits, P.: Effect of oxidant concentration, exposure time, and seed particles on secondary organic aerosol chemical composition and yield, Atmos. Chem. Phys., 15, 3063-3075, https://doi.org/10.5194/acp15-3063-2015, 2015.

Lee, A. K. Y., Hayden, K. L., Herckes, P., Leaitch, W. R., Liggio, J., Macdonald, A. M., and Abbatt, J. P. D.: Characterization of aerosol and cloud water at a mountain site during WACS 2010: secondary organic aerosol formation through oxidative cloud processing, Atmos. Chem. Phys., 12, 7103-7116, https://doi.org/10.5194/acp-12-7103-2012, 2012.

Lee, B. P., Li, Y. J., Yu, J. Z., Louie, P. K. K., and Chan, C. K.: Characteristics of submicron particulate matter at the urban roadside in downtown Hong Kong - Overview of
4 months of continuous high-resolution aerosol mass spectrometer measurements, J. Geophys. Res.-Atmos., 120, JD023311, https://doi.org/10.1002/2015JD023311, 2015.

Liu, T., Wang, X., Deng, W., Hu, Q., Ding, X., Zhang, Y., He, Q., Zhang, Z., Lü, S., Bi, X., Chen, J., and Yu, J.: Secondary organic aerosol formation from photochemical aging of lightduty gasoline vehicle exhausts in a smog chamber, Atmos. Chem. Phys., 15, 9049-9062, https://doi.org/10.5194/acp-159049-2015, 2015.

Liu, T., Liu, Q., Li, Z., Huo, L., Chan, M., Li, X., Zhou, Z., and Chan, C. K.: Emission of volatile organic compounds and production of secondary organic aerosol from stir-frying spices, Sci. Total Environ., 599-600, 1614-1621, https://doi.org/10.1016/j.scitotenv.2017.05.147, 2017.

Mao, J., Ren, X., Brune, W. H., Olson, J. R., Crawford, J. H., Fried, A., Huey, L. G., Cohen, R. C., Heikes, B., Singh, H. B., Blake, D. R., Sachse, G. W., Diskin, G. S., Hall, S. R., and Shetter, R. E.: Airborne measurement of $\mathrm{OH}$ reactivity during INTEX-B, Atmos. Chem. Phys., 9, 163-173, https://doi.org/10.5194/acp-9163-2009, 2009.

Mohr, C., DeCarlo, P. F., Heringa, M. F., Chirico, R., Slowik, J. G., Richter, R., Reche, C., Alastuey, A., Querol, X., Seco, R., Peñuelas, J., Jiménez, J. L., Crippa, M., Zimmermann, R., Baltensperger, U., and Prévôt, A. S. H.: Identification and quantification of organic aerosol from cooking and other sources in Barcelona using aerosol mass spectrometer data, Atmos. Chem. Phys., 12, 1649-1665, https://doi.org/10.5194/acp-121649-2012, 2012.

Ng, N. L., Canagaratna, M. R., Zhang, Q., Jimenez, J. L., Tian, J., Ulbrich, I. M., Kroll, J. H., Docherty, K. S., Chhabra, P. S., Bahreini, R., Murphy, S. M., Seinfeld, J. H., Hildebrandt, L., Donahue, N. M., DeCarlo, P. F., Lanz, V. A., Prévôt, A. S. H., Dinar, E., Rudich, Y., and Worsnop, D. R.: Organic aerosol components observed in Northern Hemispheric datasets from Aerosol Mass Spectrometry, Atmos. Chem. Phys., 10, 46254641, https://doi.org/10.5194/acp-10-4625-2010, 2010.

Ng, N. L., Canagaratna, M. R., Jimenez, J. L., Chhabra, P. S., Seinfeld, J. H., and Worsnop, D. R.: Changes in organic aerosol composition with aging inferred from aerosol mass spectra, Atmos. Chem. Phys., 11, 6465-6474, https://doi.org/10.5194/acp11-6465-2011, 2011.

Pajunoja, A., Lambe, A. T., Hakala, J., Rastak, N., Cummings, M. J., Brogan, J. F., Hao, L., Paramonov, M., Hong, J., Prisle, N. L., Malila, J., Romakkaniemi, S., Lehtinen, K. E. J., Laaksonen, A., Kulmala, M., Massoli, P., Onasch, T. B., Donahue, N. M., Riipinen, I., Davidovits, P., Worsnop, D. R., Petäjä, T., and Virtanen, A.: Adsorptive uptake of water by semisolid secondary organic aerosols, Geophys Res Lett, 42, 3063-3068, https://doi.org/10.1002/2015GL063142, 2015.

Pankow, J. F. and Asher, W. E.: SIMPOL.1: a simple group contribution method for predicting vapor pressures and enthalpies of vaporization of multifunctional organic compounds, Atmos. Chem. Phys., 8, 2773-2796, https://doi.org/10.5194/acp-8-27732008, 2008.

Peng, Z., Day, D. A., Ortega, A. M., Palm, B. B., Hu, W., Stark, H., Li, R., Tsigaridis, K., Brune, W. H., and Jimenez, J. L.: Non-OH chemistry in oxidation flow reactors for the study of atmospheric chemistry systematically examined by modeling, At- 
mos. Chem. Phys., 16, 4283-4305, https://doi.org/10.5194/acp16-4283-2016, 2016.

Petters, M. D. and Kreidenweis, S. M.: A single parameter representation of hygroscopic growth and cloud condensation nucleus activity, Atmos. Chem. Phys., 7, 1961-1971, https://doi.org/10.5194/acp-7-1961-2007, 2007.

Presto, A. A., Gordon, T. D., and Robinson, A. L.: Primary to secondary organic aerosol: evolution of organic emissions from mobile combustion sources, Atmos. Chem. Phys., 14, 5015-5036, https://doi.org/10.5194/acp-14-5015-2014, 2014.

Robinson, A. L., Donahue, N. M., Shrivastava, M. K., Weitkamp, E. A., Sage, A. M., Grieshop, A. P., Lane, T. E., Pierce, J. R., and Pandis, S. N.: Rethinking Organic Aerosols: Semivolatile Emissions and Photochemical Aging, Science, 315, 1259-1262, https://doi.org/10.1126/science.1133061, 2007.

Schauer, J. J., Kleeman, M. J., Cass, G. R., and Simoneit, B. R. T.: Measurement of Emissions from Air Pollution Sources. 4. $\mathrm{C}_{1}-$ $\mathrm{C}_{27}$ Organic Compounds from Cooking with Seed Oils, Environ. Sci. Technol., 36, 567-575, https://doi.org/10.1021/es002053m, 2002.

Schmidt, G. A., Kelley, M., Nazarenko, L., Ruedy, R., Russell, G. L., Aleinov, I., Bauer, M., Bauer, S. E., Bhat, M. K., Bleck, R., Canuto, V., Chen, Y.-H., Cheng, Y., Clune, T. L., Del Genio, A., de Fainchtein, R., Faluvegi, G., Hansen, J. E., Healy, R. J., Kiang, N. Y., Koch, D., Lacis, A. A., LeGrande, A. N., Lerner, J., Lo, K. K., Matthews, E. E., Menon, S., Miller, R. L., Oinas, V., Oloso, A. O., Perlwitz, J. P., Puma, M. J., Putman, W. M., Rind, D., Romanou, A., Sato, M., Shindell, D. T., Sun, S., Syed, R. A., Tausnev, N., Tsigaridis, K., Unger, N., Voulgarakis, A., Yao, M.-S., and Zhang, J.: Configuration and assessment of the GISS ModelE2 contributions to the CMIP5 archive, Journal of Advances in Modeling Earth Systems, 6, 141-184, https://doi.org/10.1002/2013MS000265, 2014.

Simopoulos, A. P.: The importance of the ratio of omega-6/omega3 essential fatty acids, Biomed. Pharmacother., 56, 365-379, https://doi.org/10.1016/S0753-3322(02)00253-6, 2002.

Sun, Y.-L., Zhang, Q., Schwab, J. J., Demerjian, K. L., Chen, W.N., Bae, M.-S., Hung, H.-M., Hogrefe, O., Frank, B., Rattigan, O. V., and Lin, Y.-C.: Characterization of the sources and processes of organic and inorganic aerosols in New York city with a high-resolution time-of-flight aerosol mass apectrometer, Atmos. Chem. Phys., 11, 1581-1602, https://doi.org/10.5194/acp11-1581-2011, 2011.
Sun, Y. L., Zhang, Q., Schwab, J. J., Chen, W.-N., Bae, M.-S., Hung, H.-M., Lin, Y.-C., Ng, N. L., Jayne, J., Massoli, P., Williams, L. R., and Demerjian, K. L.: Characterization of near-highway submicron aerosols in New York City with a high-resolution aerosol mass spectrometer, Atmos. Chem. Phys., 12, 2215-2227, https://doi.org/10.5194/acp-12-2215-2012, 2012.

Tkacik, D. S., Lambe, A. T., Jathar, S., Li, X., Presto, A. A., Zhao, Y. L., Blake, D., Meinardi, S., Jayne, J. T., Croteau, P. L., and Robinson, A. L.: Secondary Organic Aerosol Formation from in-Use Motor Vehicle Emissions Using a Potential Aerosol Mass Reactor, Environ. Sci. Technol., 48, 11235-11242, https://doi.org/10.1021/es502239v, 2014.

Torkmahalleh, M. A., Goldasteh, I., Zhao, Y., Udochu, N. M., Rossner, A., Hopke, P. K., and Ferro, A. R.: $\mathrm{PM}_{2.5}$ and ultrafine particles emitted during heating of commercial cooking oils, Indoor Air, 22, 483-491, https://doi.org/10.1111/j.16000668.2012.00783.x, 2012.

Volkamer, R., Jimenez, J. L., San Martini, F., Dzepina, K., Zhang, Q., Salcedo, D., Molina, L. T., Worsnop, D. R., and Molina, M. J.: Secondary organic aerosol formation from anthropogenic air pollution: Rapid and higher than expected, Geophys. Res. Lett., 33, L17811, https://doi.org/10.1029/2006g1026899, 2006.

Zhang, Q., Worsnop, D. R., Canagaratna, M. R., and Jimenez, J. L.: Hydrocarbon-like and oxygenated organic aerosols in Pittsburgh: insights into sources and processes of organic aerosols, Atmos. Chem. Phys., 5, 3289-3311, https://doi.org/10.5194/acp-5-32892005, 2005.

Zhang, Q., Jimenez, J. L., Canagaratna, M. R., Allan, J. D., Coe, H., Ulbrich, I., Alfarra, M. R., Takami, A., Middlebrook, A. M., Sun, Y. L., Dzepina, K., Dunlea, E., Docherty, K., DeCarlo, P. F., Salcedo, D., Onasch, T., Jayne, J. T., Miyoshi, T., Shimono, A., Hatakeyama, S., Takegawa, N., Kondo, Y., Schneider, J., Drewnick, F., Borrmann, S., Weimer, S., Demerjian, K., Williams, P., Bower, K., Bahreini, R., Cottrell, L., Griffin, R. J., Rautiainen, J., Sun, J. Y., Zhang, Y. M., and Worsnop, D. R.: Ubiquity and dominance of oxygenated species in organic aerosols in anthropogenically-influenced Northern Hemisphere midlatitudes, Geophys. Res. Lett., 34, L13801, https://doi.org/10.1029/2007gl029979, 2007. 